\title{
Plasma Magnesium and Zinc Levels in Infants with Infantile Colic
}

\author{
İnfantil Kolikli Bebeklerin Plazma Magnezyum ve Çinko Düzeyleri
}

Fulya BUYUKGEDIKLI' ${ }^{1}$, Meda KONDOLOT², Cigdem KARAKUKCU³ ${ }^{3}$, Selim KURTOGLU4

\begin{abstract}
1'Department of Pediatrics, Erciyes University Faculty of Medicine Kayseri, Turkey
${ }^{2}$ Department of Pediatrics, Social Pediatrics Unit, Erciyes University Faculty of Medicine Kayseri, Turkey

${ }^{3}$ Department of Biochemistry, Kayseri Training and Research Hospital, Kayseri, Turkey

${ }^{4}$ Department of Pediatric Endocrinology and Neonatology, Erciyes University Faculty of Medicine Kayseri, Turkey
\end{abstract}

\begin{abstract}
Objective: Muscle cramps, sleep disorders, and irritability due to Mg deficiency; and sleep and behavioral disorders associated with $\mathrm{Zn}$ deficiency and being cofactors in the melatonin synthesis have suggested that plasma $\mathrm{Mg}$ and $\mathrm{Zn}$ may be in lower levels in colicky infants. This study aimed to compare plasma Mg and Zn levels of colicky infants and the mothers with controls.

Material and Methods: Fifty infants diagnosed with infantile colic and 22 controls aged 1-3 months with their mothers were included in this cross-sectional study. Colic group was divided into two subgroups; Firts infants who were given Mg-containing herbals (herbals-group, $\mathrm{n=12}$ ) and second infants who were not given any $\mathrm{Mg}$ or $\mathrm{Zn}$-containing supplement (study group, $\mathrm{n}=27$ ). Plasma Mg and Zn levels were measured by Atomic Absorption Spectrophotometer on flame photometry.

Results: Mg levels (mg/dl) of the infants were not different between study group (2.46 \pm 0.27$)$ and controls $(2.37 \pm 0.25)$ $(p=0.70)$. However, plasma Mg levels were higher in the herbals-group $(2.68 \pm 1.90)$ than the study group $(2.46 \pm 0.27)$ and controls $(2.37 \pm 0.25)(p=0.04, p=0,004$; respectively). $Z n$ levels ( $\mathrm{mg} / \mathrm{dl})$ of the infants and $\mathrm{Mg}$ and $\mathrm{Zn}$ levels of the mothers were not different between the groups $(p=0.36, p=0.61, p=0.22$; respectively). In the herbals-group, four parents reported that the Mg-containing herbals were useful, but Mg levels of their infants were found similar with the infants whose parents reported that Mg-containing herbals were not useful $(p=0.79)$.
\end{abstract}

Conclusion: Plasma Mg and Zn levels of colicky infants and their mothers were not different from healthy controls in this study. Further studies are needed to determine the effect of Mg supplementation on colic severity.

Key Words: Infantile colic, Magnesium, Zinc

\section{Öz}

Amaç: Melatonin sentezinde kofaktör olmaları; Mg eksikliğine bağlı kas krampları, uyku bozuklukları, irritabilite ve Zn eksikliği ile ilișkili uyku ve davranış bozuklukları olması infantil kolikli bebeklerin plazma $\mathrm{Mg}$ ve $\mathrm{Zn}$ düzeylerinin düşük olabileceğini akla getirmiştir. Bu çalışmada infantil kolikli bebeklerin ve annelerinin plazma Mg ve Zn düzeylerinin kontrollerle karşılaştıııması amaçlanmıştır.

(1)

BUYUKGEDIKLI F KONDOLOTM KARAKUKCU C KURTOGLUS
: 0000-0003-3254-1904 : 0000-0002-1168-3228 0000-0001-9858-3272 :0000-0002-5256-0128
Conflict of Interest / Çıkar Çatışması: On behalf of all authors, the corresponding author states that there is no conflict of interest.

Ethics Committee Approval / Etik Kurul Onayı: The Ethical Committee in Erciyes University approved this study and parents' written informed consent was also obtained prior to the study.

Contribution of the Authors / Yazarların katkısı: BUYUKGEDIKLIF : Constructing the hypothesis or idea of research and/or article, Planning methodology to reach the Conclusions, Organizing, supervising the course of progress and taking the responsibility of the research/study, Taking responsibility in patient follow-up, collection of relevant biological materials, data management and reporting, execution of the experiments, Taking responsibility in logical interpretation and conclusion of the results, Taking responsibility in necessary literature review for the study, Taking responsibility in the writing of the whole or important parts of the study, Reviewing the article before submission scientifically besides spelling and grammar. KONDOLOT $\boldsymbol{M}$ : Constructing the hypothesis or idea of research and/or article, Planning methodology to reach the Conclusions, Organizing, supervising the course of progress and taking the responsibility of the research/study, Taking responsibility in patient follow-up, collection of relevant biological materials, data management and reporting, execution of the experiments, Taking responsibility in logical interpretation and conclusion of the results, Taking responsibility in necessary literature review for the study, Taking responsibility in the writing of the whole or important parts of the study, Reviewing the article before submission scientifically besides spelling and grammar. KARAKUKCU C : Taking responsibility in necessary literature review for the study, Taking responsibility in the writing of the whole or important parts of the study, Reviewing the article before submission scientifically besides spelling and grammar. KURTOGLU S: Constructing the hypothesis or idea of research and/or article, Planning methodology to reach the Conclusions, Organizing, supervising the course of progress and taking the responsibility of the research/study, , Taking responsibility in the writing of the whole or important parts of the study, Reviewing the article before submission scientifically besides spelling and grammar.

How to cite / Atıf yazım şekli : Buyukgedikli F, Kondolot M, Karakukcu C, kurtoglu S. Plasma Zinc and Magnesium Levels in Infants with Infantile Colic. Turkish J Pediatr Dis 2021; 15: 6-11.

\section{Correspondence Address:/ Yazışma Adresi:}

\section{Meda KONDOLOT}

Department of Pediatrics, Social Pediatrics Unit,

Erciyes University Faculty of Medicine Kayseri, Turkey

E-posta: medakondolot@gmail.com,
Received/ Geliş tarihi : 18.07.2019

Accepted/ Kabul tarihi : 14.11.2019

Online published 27.03 .2020

Elektronik yayın tarihi

DOI: 10.12956/tchd.593964 
Gereç ve Yöntemler: Bu kesitsel çalışmaya infantil kolik tanısı alan 1-3 aylık 50 bebek ve 22 sağlıklı kontrol anneleri ile birlikte dahil edilmiştir. Kolik grubu iki alt gruba ayrılmıştır; (1) Mg içeren bitki çayları verilen bebekler (bitki çayı grubu, n=12), (2) Mg ya da Zn içeren herhangi bir destek verilmeyen bebekler (çalışma grubu, $n=27$ ). Plazma Mg ve Zn düzeyleri flame fotometride Atomik Absorbsiyon Spektrofotometresi ile ölçülmüştür.

Bulgular: Bebeklerin Mg düzeyleri (mg/dl) açısından çalışma grubu (2.46 \pm 0.27$)$ ve kontrol grubu (2.37 \pm 0.25$)$ arasında fark yoktu ( $p=0.70)$.

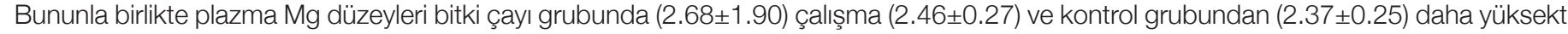
(sırasıyla p=0.04, p=0.004). Bebeklerin Zn düzeyleri, annelerinin Mg ve Zn düzeyleri gruplar arasında farklı değildi (sırasıyla p=0.36, $p=0.61$, $\mathrm{p}=0.22)$. Bitki çayı grubunda dört aile $\mathrm{Mg}$-içeren bitki çaylarından fayda gördüklerini bildirdi, ancak bebeklerinin Mg düzeyleri Mg-içeren bitki çaylarından fayda görmediğini belirten ailelerinki ile benzer bulundu $(p=0.79)$.

Sonuç: Kolikli bebeklerin ve annelerinin plazma Mg ve Zn düzeyleri sağlıklı kontrollerinden farklı değildir. Mg desteğinin kolik şiddeti üzerine etkisinin araştırıması için daha ileri çalışmalara intiyaç vardır.

Anahtar Kelimeler: İnfantil kolik, Magnezyum, Çinko

\section{INTRODUCTION}

Infantile colic is defined as inconsolable crying episodes lasts more than three hours per day, more than three days per week, and longer than three weeks, and it occurs especially during the evening (1). It affects approximately $10 \%$ to $40 \%$ of infants worldwide and peaks at around six weeks of age. Although infantile colic is known as a benign condition that resolves by three to six months of age spontaneously, it is one of the main causes of pediatric consultation because of its distress on parents (2-4).

Since the cause of infantile colic is not fully understood, there is no specific treatment. One of the proposed etiologic factors is increased serotonin effect that cause intestinal smooth muscle contractions and low melatonin level insufficient to relax intestinal smooth muscles (5-7). The rate of melatonin formation depends on the activity of arylalkylamone-N-acetyltransferase (AANAT) and its activity needs magnesium and zinc as cofactors (8-10). Although all infants have low melatonin levels in the first 3 months of life, some of them exhibit colic findings. Therefore, it was thought that low Mg or Zn levels in colicky infants may result in decreased AANAT activity and contribute to decrease in melatonin production. In a few studies, it was shown that magnesium (Mg) and zinc $(\mathrm{Zn})$ deficiencies decrease plasma melatonin levels and their supplementations increase melatonin levels (10-13).

Furthermore, it is reported that magnesium deficiency may lead to muscle cramps, sleep disorders, irritability and zinc deficiency sleep and behavioral disorders (14-16).

There is no study searching for $\mathrm{Mg}$ and $\mathrm{Zn}$ in colicky infants in the literature. In this study, we aimed to compare plasma $\mathrm{Mg}$ and $\mathrm{Zn}$ levels of colicky infants with healthy controls. Since the plasma $\mathrm{Mg}$ and $\mathrm{Zn}$ levels of the infants would be closely associated with the mothers' levels, Mg and Zn levels of the mothers were also aimed to compare.

\section{MATERIAL and METHODS}

Fifty infants aged between 4 weeks to 3 months, admitted to Well Child Clinic between June 2014 and July 2015, and

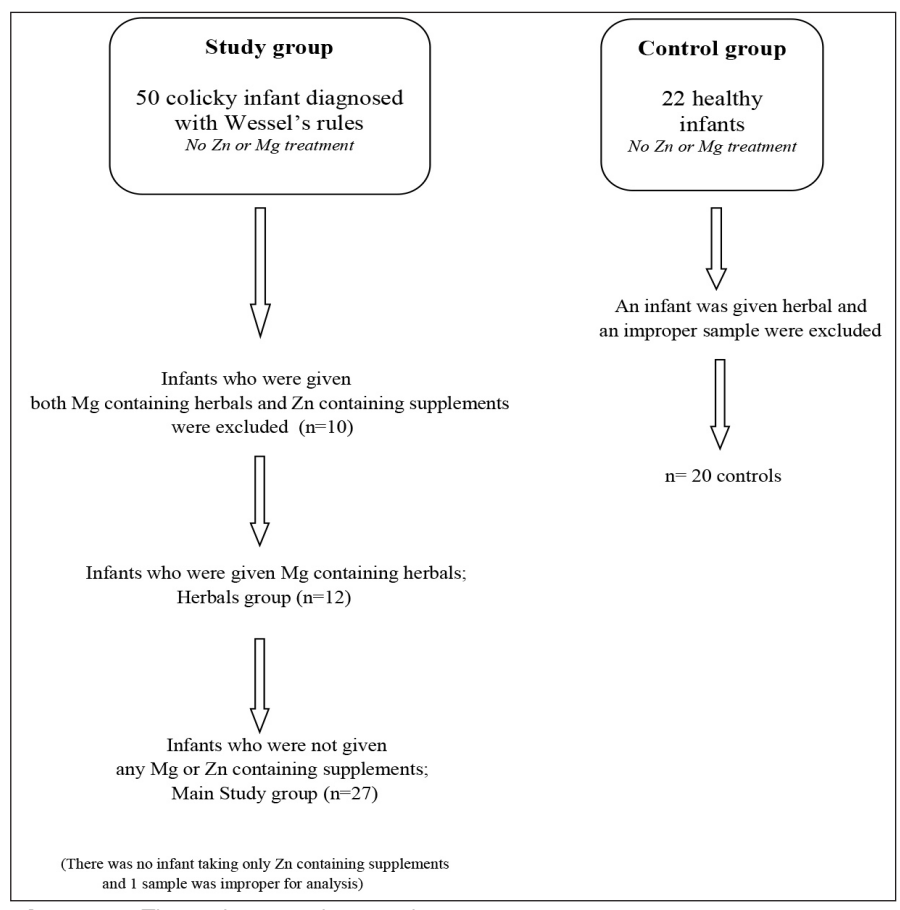

Figure 1: Flow chart of the study.

diagnosed as infantile colic according to Wessel's rules were included to the study group with their mothers. Twenty-two healthy babies were included to the control group with their mothers. The Ethical Committee in Erciyes University approved this study and parents' written informed consent was also obtained prior to the study.

The infants with congenital anomalies or those with chronic diseases, also having an acute infection or low birth weight, equal or smaller than 36 gestational weeks were excluded from the study. A questionnaire about sociodemographic features and family history was applied to both families of the study and control groups. Basic features of the study and control groups are shown in Table I.

No infants or mothers were given Zn or Mg treatment. However, in the study group there were infants who were given Mg containing herbals (cumin or fennel tea) or Zn containing food supplements. Therefore, study group divided into the subgroups but infants who were given both Mg containing herbals and $\mathrm{Zn}$ containing food supplements were not included for analysis. The flow chart of the study was shown in figure 1. 
Random venous blood samples were taken from infants and mothers included in the study and control groups. Total plasma $\mathrm{Mg}$ and $\mathrm{Zn}$ levels of infants and mothers were measured by Atomic Absorption Spectrophotometer (Thermo ICE 3000) on flame photometry. For total Mg measurement Standard Reference Material (SRM) $\mathrm{MgCl}_{2}$ in $6 \% \mathrm{HCl}$ and for $\mathrm{Zn}$ measurement $\mathrm{Zn}\left(\mathrm{NO}_{3}\right)_{2}$ were used.

Samples were diluted with lanthanum-HCL solution to reduce interference from anions and reduce viscosity. The diluted samples were aspirated into an air-acetylene flame where ground state $\mathrm{Mg}$ and $\mathrm{Zn}$ ions absorb light from hollow cathode lamps at the wavelength 285.2 and $213.9 \mathrm{~nm}$, respectively. This absorption of light was measured at wavelengths that are directly proportional to the number of ground states of $\mathrm{Mg}$ and Zn. Haemolysed samples were not used as erythrocytes contain higher concentrations of magnesium than serum or plasma. Erciyes University Scientific Research Unit funded this study.

\section{Statistical analysis}

Statistical analysis of the study was performed by using SPSS 22. Whether the distribution of numerical variables was normal or not, evaluated by the Shapiro-Wilk normality test. The mean \pm SD was used for normally distributed data, and median (minmax) for abnormal distributed data values. For the comparison of two independent groups; Independent Samples t-test was used for normally distributed data, Mann-Whitney $U$ test was used for abnormally distributed data. The chi-square $\left(X^{2}\right)$ analysis was used for the comparison of categorical variables. The one-way analysis of variance (ANOVA) was used to compare independent groups. Significance was accepted as $p<0.05$.

\section{RESULTS}

Both infantile colic and control groups were similar in terms of gender, birth weight, actual weight, birth order, gestational age, type of delivery, nutritional status, maternal age, paternal

Table I: Basic characteristics of the infants and parents.

\begin{tabular}{|c|c|c|c|}
\hline & $\begin{array}{l}\text { Study group } \\
(n=50)\end{array}$ & $\begin{array}{c}\text { Controls } \\
(n=22)\end{array}$ & $\mathbf{p}$ \\
\hline Age (days), mean $\pm S D$ & $51.6 \pm 18.09$ & $63.5 \pm 19.8$ & 0.020 \\
\hline $\begin{array}{l}\text { Gender, } \mathbf{n}(\%) \\
\text { Female } \\
\text { Male }\end{array}$ & $\begin{array}{l}24(48) \\
26(52)\end{array}$ & $\begin{array}{c}8(36.4) \\
14(63.6)\end{array}$ & 0.360 \\
\hline Gestational age, mean \pm SD & $38 \pm 1.4$ & $38.5 \pm 1.4$ & 0.100 \\
\hline Birth weight $(g)$, mean $\pm S D$ & $3033.7 \pm 438.9$ & $3117.7 \pm 502.1$ & 0.650 \\
\hline $\begin{array}{l}\text { Type of delivery, n(\%) } \\
\text { Vaginal } \\
\text { Cesarean section }\end{array}$ & $\begin{array}{l}20(40) \\
30(60)\end{array}$ & $\begin{array}{l}11(50) \\
11(50)\end{array}$ & 0.430 \\
\hline Actual weight (g) & $4842.6 \pm 871.1$ & $5149.1 \pm 852.7$ & 0.060 \\
\hline $\begin{array}{l}\text { Birth order } \\
1 \\
2 \\
\geq 3\end{array}$ & $\begin{array}{l}26(52) \\
11(22) \\
13(26)\end{array}$ & $\begin{array}{l}9(41) \\
9(41) \\
4(18)\end{array}$ & 0.250 \\
\hline Mother's age, mean \pm SD & $27.64 \pm 5.36$ & $27.4 \pm 6.3$ & 0.840 \\
\hline Father's age, mean $\pm S D$ & $31.5 \pm 5.8$ & $30.7 \pm 5.5$ & 0.870 \\
\hline $\begin{array}{l}\text { Mother education (years) } \\
\leq 5 \\
6-11 \\
\geq 12\end{array}$ & $\begin{array}{l}11(22) \\
28(56) \\
11(22)\end{array}$ & $\begin{array}{c}3(14) \\
13(59) \\
6(27)\end{array}$ & 0.690 \\
\hline $\begin{array}{l}\text { Mother's job, } \mathbf{n}(\%) \\
\text { House wife } \\
\text { Working }\end{array}$ & $\begin{array}{l}42(84) \\
8(16)\end{array}$ & $\begin{array}{c}18(82) \\
4(18)\end{array}$ & 0.820 \\
\hline History of gestational diabetes, $\mathrm{n}(\%)$ & $5(10)$ & $2(9)$ & 1.000 \\
\hline History of preeclampsia, $n(\%)$ & $3(6)$ & $2(9)$ & 0.640 \\
\hline Weight gain during pregnancy $(\mathbf{k g})$ & $11.35 \pm 4.6$ & $13.36 \pm 4.9$ & 0.190 \\
\hline $\begin{array}{l}\text { Mother smoking status, } \mathbf{n}(\%) \\
\text { During pregnancy } \\
\text { During lactation }\end{array}$ & $\begin{array}{l}9(18) \\
8(16)\end{array}$ & $\begin{array}{c}1(5) \\
1(4.5)\end{array}$ & $\begin{array}{l}0.130 \\
0.120\end{array}$ \\
\hline $\begin{array}{l}\text { Feeding pattern, } \mathbf{n}(\%) \\
\text { Exclusively breastfeeding } \\
\text { Breastfeeding plus formula feeding }\end{array}$ & $\begin{array}{l}34(68) \\
16(32) \\
\end{array}$ & $\begin{array}{l}14(64) \\
8(36)\end{array}$ & 0.710 \\
\hline
\end{tabular}


Table II: Plasma magnesium and zinc levels of infants and mothers in the study subgroups and controls.

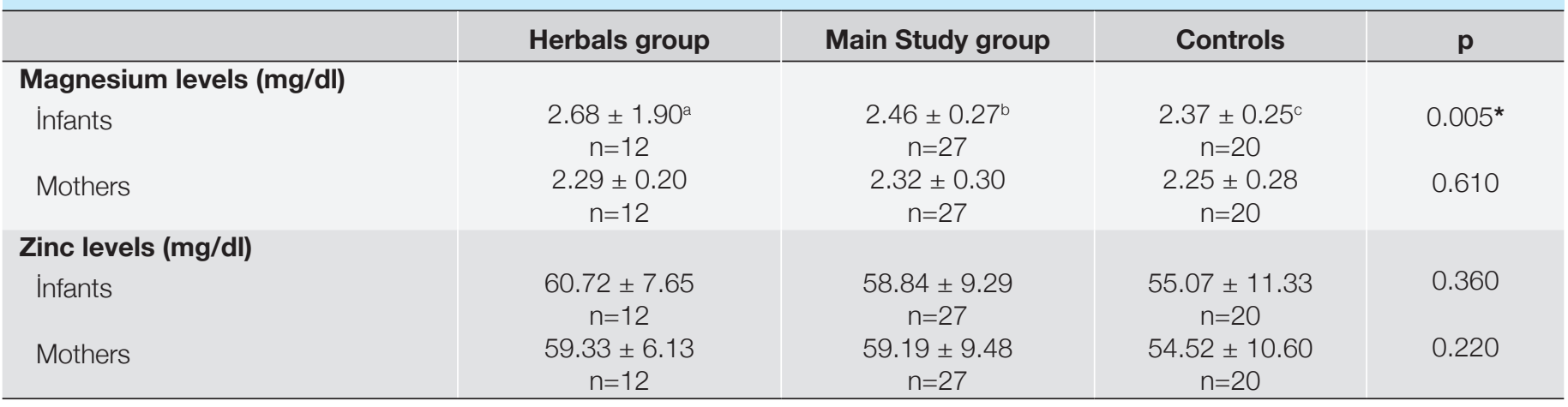

*Post hoc bonferroni a/c ( $p=0.004), a / b(p=0.04), b / c(p=0.70)$

Table III: Plasma magnesium and zinc levels of colicky infants according to the feeding pattern.

\begin{tabular}{l|c|c|c}
\hline & Exclusively breastfeeding $\mathbf{n = 3 4}$ & Breastfeeding plus formula $\mathbf{n = 1 5}$ & $\mathbf{p}$ \\
\hline Magnesium levels (mg/dl) & $2.49 \pm 0.32$ & $2.55 \pm 0.21$ & 0.610 \\
\hline Zinc levels (mg/dl) & $58.68 \pm 9.19$ & $57.63 \pm 13.27$ & 0.480 \\
\hline
\end{tabular}

age, maternal work and education status, mother's weight gain during pregnancy, presence of gestational diabetes, preeclampsia history and maternal smoking status. The mean age of the control group (63.5 \pm 19.8 days) was higher than the colic group (51.6 \pm 18 days) ( $\mathrm{p}=0.02)$ (Table I).

Plasma Mg levels ( $\mathrm{mg} / \mathrm{dl}$ ) of the infants were not different between study group (2.46 \pm 0.27$)$ and controls $(2.37 \pm 0.25)(p=0.70)$. $\mathrm{Mg}$ levels were higher in the herbals group $(2.68 \pm 1.90)$ than the study group and controls ( $p=0.04, p=0,004$; respectively). Plasma $\mathrm{Zn}$ levels $(\mathrm{mg} / \mathrm{dl})$ of the infants were not different between the groups ( $p=0.36)$. Plasma $M g$ and $Z n$ levels of the mothers were also not different between the groups $(p=0.61$, $\mathrm{p}=0.22$; respectively) (Table II).

Four parents in the herbals group (33\%) reported that they get benefit from the Mg-contain herbals, but Mg levels was similar with the parents who reported that they do not get benefit (67\%) [Plasma Mg levels $2.71 \pm 0.13 ; 2.67 \pm 0.21 \mathrm{mg} / \mathrm{dl}$ respectively] $(p=0.79)$.

Plasma Mg and Zn levels of colicky infants were not different between the exclusively breastfeeding and breastfeeding plus formula feeding groups ( $p=0.61, p=0.48$; respectively) (Table III).

\section{DISCUSSION}

Infantile colic occurs in the first 3 months of life, especially in the periods that melatonin effect is expected and improves during the 3-6th months which circadian rhythm develops. Although it was thought to be a physiological process, not seen in each baby or having different severity in every baby, suggesting the existence of certain factors that could affect levels of melatonin. Rate of the melatonin formation depends on the activity of
arylalkylamone-N-acetyltransferase (AANAT) and its activity needs magnesium (Mg) and zinc (Zn) as cofactors (8-10). There are studies indicating that decreased melatonin levels in the absence of $\mathrm{Mg}$ and $\mathrm{Zn}$ and elevated levels after replacement (10-13). Increased AANAT activity was also reported in rats with Mg supplementation (10). Biological clock and magnesium status are also reported to be linked $(17,18)$. On the other hand, independently of melatonin, magnesium has function on muscle contraction/relaxation, neurotransmitter release, neuromuscular impulse conduction and its deficiency cause irritability, sleep disorders, and muscle spasm (14). Low levels of magnesium have also been found to be associated with migraine such that infantile colic has been accepted early sign of migraine $(19,20)$. Zinc deficiency also leads to sleep disorders and neurobehavioral abnormalities $(15,16)$. For these reasons, it was thought that colicky infants may have lower plasma Mg or $\mathrm{Zn}$ levels than healthy controls and this could be the cause of colic symptoms. In this study, we aimed to compare plasma Mg and $\mathrm{Zn}$ levels of colicky infants with healthy controls.

None of the infants or mothers included into the study, had history of Mg treatment. However, 12 colicky infants were given herbal supplements (cumin or fennel tea) by their families for colic symptoms, and they were evaluated as a subgroup. Although the amount and duration of the herbal supplements were not known, because 2 grams of fennel seeds contain 8 $\mathrm{mg} \mathrm{Mg}, 2.1 \mathrm{gr}$ cumin seeds contain $8 \mathrm{mg} \mathrm{Mg}$ they could affect plasma Mg levels (21). Thus, Mg levels of infants who were given herbal tea were higher than the controls and the study group. Plasma Mg levels of the mothers were also searched as the mothers' levels would affect the plasma Mg levels of their babies and no difference was found between the groups (Table II). Higher Mg levels in the herbal group could be due to cumin or fennel teas in this study. 
Both pregnancy and lactation periods are risky periods for hypomagnesaemia (22). However, in this study there was no case with hypomagnesaemia neither in mother nor in the infant groups.

It is difficult to determine the exact $\mathrm{Mg}$ levels in the body. Despite the reduction in total plasma Mg levels in the cases with Mg deficiency, plasma Mg levels may also be measured as normal $(23,24)$. However, the most commonly used method to analyze the plasma levels. In the studies of adults, it has been shown to be effective to use Mg, for example in acute migraine headaches $(14,25)$. For infants it is not reliable to use direct Mg supplementation, preliminary we aimed to compare plasma levels. However, there were infants in the study group that their parents had used herbal tea for colic. Although the amount and duration of the herbal supplements were not known, we found that Mg levels of the infants who were given herbals were higher than controls. According to the parents reports 4 colicky infants get benefit from the Mg containing herbals and 8 not. Their Mg levels were also not different, but the number of groups was small. Herbals are used as a traditional soothing method to relief gastrointestinal symptoms and its effectiveness is not clear for infantile colic (26). However, their relaxing mechanism is also not clear. In a study, an emulsion of $0.1 \%$ of fennel seed oil was compared with placebo and after a 7-day trial, a significant improvement in colic symptoms and cumulative crying time was observed (27). In further prospective studies, mothers should be followed from the pregnancy periods in terms of $\mathrm{Mg}$ deprivation and effect of $\mathrm{Mg}$ supplementation to the mothers or infants may be needed to be searched with larger numbers of the infant and colic severity should be followed.

Plasma Zn levels of infants and mothers were not different between the colicky infants and controls in this study. None of the infants or mothers included into the study, had also history of $\mathrm{Zn}$ treatment. Ten of the infants were given both $\mathrm{Mg}$ and $\mathrm{Zn}$ containing food supplement and this group was excluded from the analysis. On the other hands, $\mathrm{Zn}$ levels of the mothers and infants were observed lower than the expected normal values. In the literature, significant decreases in the levels of zinc during pregnancy and a progressive decline in the zinc concentrations of breastmilk as the duration of lactation increased was reported in developing countries (28). Similarly, with Mg, effect of Zn supplementation may be needed to be searched in prospective studies.

There are some limitations in this study. As mentioned above, it is difficult to determine the exact $\mathrm{Mg}$ and $\mathrm{Zn}$ levels via plasma. Another limitation of this study is that, we could not measure melatonin levels together with plasma $\mathrm{Mg}$ and $\mathrm{Zn}$ levels. Because of the daily melatonin secretion is rhythmic, has a short half-life, not stored and affected from light, measurement of melatonin levels could not be possible.

In this study, there was no difference in terms of sex, birth weight, current weight, birth order, gestational age, nutritional status, maternal age, paternal age, maternal work and education status, weight gain during pregnancy, gestational diabetes, preeclampsia history and maternal smoking features between the groups. The mean age of the control group was found to be greater than the colic group; but this strengthened the study as it indicated that absence of colic symptoms in the control group. Plasma Mg and Zn levels of colicky infants were also not different according to the feeding pattern (exclusively breastfeeding vs breastfeeding plus formula feeding).

This is the first study investigating the plasma levels of magnesium and zinc in colicky infants. Plasma $\mathrm{Mg}$ and $\mathrm{Zn}$ levels of colicky infants and their mothers' were not different from healthy controls in this study. However, further studies with larger numbers are needed to determine the effect of $\mathrm{Mg}$ or $\mathrm{Zn}$ supplementation on colic severity.

\section{REFERENCES}

1. Wessel MA, Cobb JC, Jackson EB, Harris GS, Detwilter BA. Paroxysmal fussing in infancy, sometimes called "colic". Pediatrics 1954;14:421-33.

2. Savino F. Focus on infantile colic. Acta Paediatr 2007;96:1259-64.

3. Savino F, Benetti S, Ceratto S. Infantile colic: from symptoms to diagnosis - A practical approach. J Symptoms and Signs 2013;2:248-52.

4. Yalçin SS, Orün E, Mutlu B, Madendağ Y, Sinici I, Dursun A, et al. Why are they having infant colic? A nested case-control study. Paediatr Perinat Epidemiol 2010;24:584-96.

5. Weissbluth $L$ and Weissbluth $M$. Infant colic: the effect of serotonin and melatonin circadian rhythms on the intestinal smooth muscle. Med Hypotheses 1992;39:164-7.

6. Kurtoglu S, Uzüm K, Hallac IK, Coskum A. 5-Hydroxy-3indole acetic acid levels in infantile colic: is serotoninergic tonus responsible for this problem? Acta Paediatr 1997;86:764-65.

7. Ince $T$, Akman $H$, Çimrin D, Aydın A. The role of melatonin and cortisol circadian rhythms in the pathogenesis of infantile colic. World J Pediatr 2018;14:392-8.

8. Peuhkuri K, Sihvola N, Korpela R. Dietary factors and fluctuating levels of melatonin. Food Nutr Res 2012;56:2-14.

9. Morton DJ. Possible mechanisms of inhibition and activation of rat $\mathrm{N}$-acetyltransferase (EC 2.3.1.5.) by cations. J Neural Transm 1989;75:51-64.

10. Morton DJ, James MF. Effect of magnesium ions on rat pineal $\mathrm{N}$-acetyltransferase (EC 2.3.1.5) activity. J Pineal Res 1985;2:38791.

11. Billyard AJ, Eggett DL, Franz KB. Dietary magnesium deficiency decreases plasma melatonin in rats. Magnes Res 2006;19:157-61.

12. Bediz CS, Baltaci AK, Mogulkoc R. Both zinc deficiency and supplementation affect plasma melatonin levels in rats. Acta Physiol Hung 2003;90:335-9.

13. Abbasi B, Kimiagar M, Sadeghniiat K, Shirazi MM, Hedayati M, Rashidkhani B. The effect of magnesium supplementation on primary insomnia in elderly: A double-blind placebo-controlled clinical trial. J Res Med Sci 2012;17:1161-9.

14. Gröber U, Schmidt J, Kisters K. Magnesium in Prevention and Therapy. Nutrients 2015;7:8199-226. 
15. Kambe T, Fukue K, Ishida R, Miyazaki S. Overview of Inherited Zinc Deficiency in Infants and Children. J Nutr Sci Vitaminol. (Tokyo) 2015;61 Suppl:S44-6.

16. Yang R, Zhang Y, Gao W, Lin N, Li R, Zhao Z. Blood Levels of Trace Elements in Children with Attention-Deficit Hyperactivity Disorder: Results from a Case Control Study. Biol Trace Elem Res 2019;187:376-82.

17. Durlach J, Pagès N, Bac P, Bara M, Guiet-Bara A. Biorhythms and possible central regulation of magnesium status, phototherapy, darkness therapy and chronopathological forms of magnesium depletion. Magnes Res 2002;15:49-66.

18. Durlach J, Pagès N, Bac P, Bara M, Guiet-Bara A, Agrapart C. Chronopathological forms of magnesium depletion with hypofunction or with hyperfunction of the biological clock. Magnes Res 2002;15:263-8.

19. Gonullu H, Gonullu E, Karadas S, Arslan M, Kalemci O, Aycan A, et al. The levels of trace elements and heavy metals in patients with acute migraine headache. J Pak Med Assoc 2015;65:694-97.

20. Qubty W, Gelfand AA. The Link Between Infantile Colic and Migraine. Curr Pain Headache Rep 2016;20:31.

21. USDA National Nutrient Database for Standard Reference Release 27 December 30, 2014.
22. Durlach J. New data on the importance of gestational Mg deficiency. J Am Coll Nutr 2004;23:694S-700.

23. Elin RJ. Assessment of magnesium status. Clin Chem 1987;33:1965-70.

24. Reinhart RA. Magnesium metabolism: A review with a special reference to the relationship between intracellular content and serum levels. Arch Intern Med 1988;148: 2415-20.

25. Chiu HY, Yeh TH, Huang YC, Chen PY. Effects of Intravenous and Oral Magnesium on Reducing Migraine: A Meta-analysis of Randomized Controlled Trials. Pain Physician 2016;19:E97-112.

26. Anheyer D, Frawley J, Koch AK, Lauche R, Langhorst J, Dobos G, et al. Herbal Medicines for Gastrointestinal Disorders in Children and Adolescents: A Systematic Review. Pediatrics 2017;139.

27. Alexandrovich I, Rakovitskaya O, Kolmo E, Sidorova T, Shushunov $\mathrm{S}$. The effect of fennel (Foeniculum Vulgare) seed oil emulsion in infantile colic: a randomized, placebo-controlled study. Altern Ther Health Med 2003;9:58-61.

28. Ejezie F, Nwagha U. Zinc Concentration during Pregnancy and Lactation in Enugu, South-East Nigeria. Ann Med Health Sci Res 2011;1:69-76. 